\title{
SATISFACTION SURVEY OF PATIENTS FOR TELEMEDICINE CONSULTATION DURING COVID 19 TRANSMISSIONS
}

\author{
Stuti Debnath \\ Kolkata, India, 2021
}

\begin{abstract}
Telemedicine was defined by the World Health Organization as "the delivery of health care services by all health care professionals using technology for the exchange of valid information for the diagnosis, treatment, and prevention of disease and injuries". In the current scenario of COVID19 , telemedicine played a vital role in our live by saving our time and also by helping us in maintaining the social distancing norms. Telemedicine consultation helps to minimize the spread of the virus by providing all kind of health care services without the need of going to the close contact to the clinicians. In our city both government and private hospitals have actively participated and provided their every possible way of contribution to various telemedicine activities. The aim $\&$ objective of this study is to find out, satisfaction of the patients in using telemedicine consultation during COVID-19 pandemic. A Survey was administered among 30 patients who had received at least one or more than one telemedicine consultation to know the satisfaction for telemedicine consultation during this COVID-19 pandemic. The survey was done among 30 people between the age group of 30 above 60 year during the year 2021 . The survey was done through Google Form. Participants responded to survey questions about their telemedicine consultation during COVID-19 pandemic. The result of the survey shows, $60 \%$ people from $30-40$ age group, $6.7 \%$ people from $\quad 41-50$ age group, $23.3 \%$ people from $51-60$ age group \& $10 \%$ people from above 60 age group used telemedicine during this pandemic. My survey also shows that $20 \%$ for new complaint, $16.7 \%$ follow up, $33.3 \%$ for
\end{abstract}

emergency \& 30\% for covid 19 related reasons used telemedicine and it also shows that $30 \%$ people for sick or well check, $40 \%$ people used for safety, $26.7 \%$ people used to save time and $3.3 \%$ people used telemedicine for other reason for most recent visit. From my study I found out that $53.3 \%$ people used telephone $\& 20 \%$ used video conference and $26.7 \%$ people used both way for consultation. Moreover $90 \%$ people agreed over the fact that telemedicine made healthcare easier during COVID 19 but $10 \%$ people not agreed with this fact, along with this during telemedicine consultation $13.3 \%$ people faced delayed response , $6.7 \%$ faced long waiting time \& $80 \%$ faced punctual timing. Along with positive sides the study also shows that there are $33.3 \%$ people who experienced unsolved medical issues but there are also $66.7 \%$ people who didn't receive any unsolved issues. My study shows that $26.7 \%$ people had better experience of telemedicine consultation compare to in-person visit, $10 \%$ people had just as good experience of telemedicine consultation compare to in-person visit, $63.3 \%$ people had worse experience of telemedicine consultation compare to in-person visit. During this pandemic of covid through this survey it is found that $93.3 \%$ people recommended of using telemedicine to a family member or friend \& $6.7 \%$ people don't recommend using of telemedicine to family member or friend. In the sector of usefulness of medical appointment with telemedicine after the covid 19 emergency is over, it shows that $86.7 \%$ people think medical appointment with telemedicine is very useful after covid $19 \& 13.3 \%$ people think medical appointment with telemedicine is not useful at all after covid 19 and also $\mathbf{5 3 . 3 \%}$ 
people prefer \& $6.7 \%$ people don't prefer using telemedicine consultation in future for health issues and $40 \%$ people maybe prefer using telemedicine consultation in future for health issues.

\section{INTRODUCTION}

The COVID-19 outbreak was officially declared a pandemic by the World Health Organization on March 11, 2020. To help in minimize the spread of COVID-19, different health care systems have rapidly adopted different kind of alternative models for health care delivery. In different places before the arrival of COVID-19, telemedicine was increasingly being adopted to bring specialty care into the homes of seriously ill patients and their families. Patients who receive care by telemedicine are very satisfied with the incredible way of treatment and timeliness of the treatment. Telemedicine also saves valuable times of both doctors and patients. During the current pandemic, telemedicine has the potential to help to get the access to quality, affordable care for patients while maintaining physical distancing for the safety of both patients and providers. Telemedicine has been considered as an ideal way to face this emergency situation. The widespread adoption of telemedicine is linked with the COVID-19 pandemic and may have a significant and durable impact on health care system. A lot of countries implemented teleconsultation during the COVID-19 pandemic. There are many hospitals that are providing telemedicine services free of cost. So the people who are unable to afford treatment during this pandemic easily can have access to telemedicine consultation. Moreover, Telemedicine consultation helps us to maintain social distancing norms which really necessary now to break the chain of COVID-19. Not only now, also in the coming years telemedicine is going to be a very important part of our life as it is more convenient $\&$ affordable way of treatment. The COVID-19 pandemic is making changes in health sectors and increasing the need to apply telemedicine consultation more firmly. The utilization of telemedicine helps us in continuing to provide care and on the other hand also keep patients and health providers safe during the outbreak. So, in the current scenario Telemedicine is a very important part. So in this context, I assessed patient satisfaction on using telemedicine consultation during this COVID -19 pandemic.

\section{METHODOLOGY}

A Survey was administered among 30 patients who had received at least one or more than one telemedicine consultation to know the satisfaction for telemedicine consultation during this COVID-19 pandemic. The survey was done among 30 people between the age group of 30 - above 60 year in JUNE month during the year 2021. The survey was done through Google Form. Participants responded to survey questions about their telemedicine consultation during COVID-19 pandemic.

\section{EXPERIMENT \& RESULT}

TABLE NO.1

\begin{tabular}{|l|l|}
\hline VARIABLE & PERCENTAGE \\
\hline $30-40$ & $60 \%$ \\
\hline $41-50$ & $6.7 \%$ \\
\hline $51-60$ & $23.3 \%$ \\
\hline ABOVE 60 & $10 \%$ \\
\hline
\end{tabular}

Table 1 represents that $60 \%$ people are from $30-40$ age group, $6.7 \%$ people are from $41-50$ age group, $23.3 \%$ people are from 51-60 age group and $10 \%$ people are from above 60 age group.

TABLE NO. 2

\begin{tabular}{|l|l|}
\hline VARIABLE & PERCENTAGE \\
\hline MEDICINE & $76.7 \%$ \\
\hline CARDIOLOGY & $3.3 \%$ \\
\hline GASTROENTEROLOGY & $3.3 \%$ \\
\hline ENT & $3.3 \%$ \\
\hline ORTHOPEDICS & $3.3 \%$ \\
\hline GYNECOLOGY & $3.3 \%$ \\
\hline NEUROLOGY & $3.3 \%$ \\
\hline THYROID & $6.7 \%$ \\
\hline
\end{tabular}

Table 2 represents under which category people used telemedicine. Graph 2 \& Table 2 represent that $3.3 \%$ people for ENT, $3.3 \%$ people for GYNECOLOGY, $6.7 \%$ people for THYROID, $3.3 \%$ people for GASTROENTEROLOGY, $3.3 \%$ people for 
NEUROLOGY, $3.3 \%$ people for CARDIOLOGY and $76.75 \%$ people for MEDICINE department used telemedicine consultation.

TABLE NO. 3

\begin{tabular}{|l|l|}
\hline VARIABLE & PERCENTAGE \\
\hline $\begin{array}{l}\text { OUTPATIENT } \\
\text { CLINIC } \\
\text { NURSES }\end{array}$ & $16.7 \%$ \\
\hline $\begin{array}{l}\text { ATTENDING } \\
\text { PHYSICIANS }\end{array}$ & $30 \%$ \\
\hline $\begin{array}{l}\text { MEDIA } \\
\text { REPORT }\end{array}$ & $43.3 \%$ \\
\hline OTHERS & $10 \%$ \\
\hline
\end{tabular}

Table 3 represents that $30 \%$ from ATTENDING PHYSICIANS, $43.3 \%$ from MEDIA REPORT, $16.7 \%$ from OUTPATIENT CLINIC NURSES and $10 \%$ from OTHER way is the source of knowing about telemedicine consultation.

TABLE NO. 4

\begin{tabular}{|l|l|}
\hline VARIABLE & PERCENTAGE \\
\hline $\begin{array}{l}\text { NEW } \\
\text { COMPLAINT }\end{array}$ & $20 \%$ \\
\hline FOLLOW UP & $16.7 \%$ \\
\hline EMERGENCY & $33.3 \%$ \\
\hline $\begin{array}{l}\text { COVID } \\
\text { RELATED }\end{array}$ & $30 \%$ \\
\hline
\end{tabular}

Table 4 represents the reason of using telemedicine consultation. Table 4 represent that $20 \%$ for NEW COMPLAINT, $33.3 \%$ for EMERGENCY, 30\% for COVID-19 RELATED and $16.7 \%$ for FOLLOW UP used telemedicine consultation.

TABLE NO. 5

\begin{tabular}{|l|l|}
\hline VARIABLE & PERCENTAGE \\
\hline $\begin{array}{l}\text { SICK OR WELL } \\
\text { CHECK }\end{array}$ & $30 \%$ \\
\hline SAFETY & $40 \%$ \\
\hline SAVE TIME & $26.7 \%$ \\
\hline
\end{tabular}

\begin{tabular}{|l|l|}
\hline OTHERS & $3.3 \%$ \\
\hline
\end{tabular}

Table 5 represents that $40 \%$ for SAFETY, $30 \%$ for SICK OR WELL-CHECK, $26.7 \%$ to SAVE TIME and $3.3 \%$ for OTHER reason used telemedicine for most recent visit.

TABLE NO. 6

\begin{tabular}{|c|l|}
\hline VARIABLE & PERCENTAGE \\
\hline 1 MONTH & $60 \%$ \\
\hline 2 MONTHS & $20 \%$ \\
\hline 3 MONTHS & $20 \%$ \\
\hline
\end{tabular}

Table 6 represents that $60 \%$ people for $1 \mathrm{MONTH}$ duration, $20 \%$ people for 2 MONTHS duration \& $20 \%$ people for 3 MONTHS duration did consultation through telemedicine.

TABLE NO. 7

\begin{tabular}{|l|l|}
\hline VARIABLE & PERCENTAGE \\
\hline ONE & $66.7 \%$ \\
\hline $\begin{array}{l}\text { MORE } \\
\text { THAN ONE }\end{array}$ & $33.3 \%$ \\
\hline
\end{tabular}

Table 7 represents that $66.7 \%$ people ONE \& $33.3 \%$ people MORE THAN ONE telemedicine consultation appointments had.

TABLE NO.8

\begin{tabular}{|l|l|}
\hline VARIABLE & PERCENTAGE \\
\hline \hline TELEPHONE & $53.3 \%$ \\
\hline $\begin{array}{l}\text { VIDEO } \\
\text { CONFERENCE }\end{array}$ & $20 \%$ \\
\hline BOTH & $26.7 \%$ \\
\hline
\end{tabular}

Table 8 represents that $20 \%$ people through VIDEO CONFERENCE, $53.3 \%$ people through TELEPHONE \& $26.7 \%$ people through BOTH WAY had telemedicine consultation. 
TABLE NO. 9

\begin{tabular}{|l|l|}
\hline VARIABLE & PERCENTAGE \\
\hline YES & $20 \%$ \\
\hline NO & $56.7 \%$ \\
\hline MAYBE & $23.3 \%$ \\
\hline
\end{tabular}

Table 9 represents if the presence of camera or other equipment made uncomfortable while telemedicine consultation. In answer of this $20 \%$ people said YES, means presence of camera or other equipment made them uncomfortable, $56.7 \%$ people said NO, means presence of camera or other equipment didn't make them uncomfortable \& $23.3 \%$ people said MAYBE, means maybe presence of camera or other equipment made them uncomfortable.

TABLE NO. 10

\begin{tabular}{|c|l|}
\hline VARIABLE & PERCENTAGE \\
\hline AGREE & $90 \%$ \\
\hline $\begin{array}{l}\text { I DON'T } \\
\text { AGREE }\end{array}$ & $10 \%$ \\
\hline
\end{tabular}

Table 10 represents that $90 \%$ people AGREE \& $10 \%$ people DON'T AGREE that telemedicine services made healthcare easier today during COVID 19.

TABLE NO. 11

\begin{tabular}{|l|l|}
\hline VARIABLE & PERCENTAGE \\
\hline YES & $66.7 \%$ \\
\hline NO & $33.3 \%$ \\
\hline
\end{tabular}

Table 11 represents if ever reconsulted with the same doctor, consulted before through telemedicine. It shows $66.7 \%$ people said YES, means they consulted with the same doctor through telemedicine \& $33.3 \%$ people said NO, means they didn't reconsult with the same doctor through telemedicine.
TABLE NO. 12

\begin{tabular}{|l|l|}
\hline VARIABLE & PERCENTAGE \\
\hline $\begin{array}{l}\text { REASSURANCE } \\
\text { \& SELF } \\
\text { MANAGEMENT }\end{array}$ & $33.3 \%$ \\
\hline $\begin{array}{l}\text { PRESCRIBED } \\
\text { DRUGS }\end{array}$ & $50 \%$ \\
\hline APPOINTMENT & $16.7 \%$ \\
\hline
\end{tabular}

Table 12 represents the outcome of treatment from telemedicine consultation. It shows that $16.7 \%$ people have APPOINTMENT, 33.3\% people got REASSURANCE \& SELF-MANAGEMENT \& $50 \%$ people got prescribed drugs as outcome of the telemedicine consultation.

TABLE NO. 13

\begin{tabular}{|l|l|}
\hline VARIABLE & PERCENTAGE \\
\hline $\begin{array}{l}\text { DELAYED } \\
\text { RESPONSE }\end{array}$ & $13.3 \%$ \\
\hline $\begin{array}{l}\text { LONG } \\
\text { WAITING } \\
\text { TIME }\end{array}$ & $6.7 \%$ \\
\hline $\begin{array}{l}\text { PUNCTUAL } \\
\text { TIMING }\end{array}$ & $80 \%$ \\
\hline
\end{tabular}

Table 13 represents the response \& waiting in telemedicine consultation. It shows that $6.7 \%$ people experienced LONG WAITING TIME, $13.3 \%$ people experienced DELAYED RESPONSE \& 80\% people experienced PUNCTUAL TIMING in telemedicine consultation.

TABLE NO. 14

\begin{tabular}{|l|l|}
\hline VARIABLE & PERCENTAGE \\
\hline YES & $33.3 \%$ \\
\hline NO & $66.7 \%$ \\
\hline
\end{tabular}

Table no. 14 represents count of unsolved medical issues which is not solved through telemedicine consultation. It shows $33.3 \%$ people said YES, means $33.3 \%$ people faced unsolved medical issues by using telemedicine consultation and $66.7 \%$ people said NO, means $66.7 \%$ people didn't face any unsolved medical issues. 
TABLE NO. 15

\begin{tabular}{|l|l|}
\hline VARIABLE & PERCENTAGE \\
\hline $\begin{array}{l}\text { THEY GAVE ME AN } \\
\text { APPOINTMENT } \\
\text { WITHOUT } \\
\text { EXPLAINING MY } \\
\text { PROBLEM }\end{array}$ & $53.3 \%$ \\
\hline $\begin{array}{l}\text { MY PROBLEM WAS } \\
\text { NOT SOLVED }\end{array}$ & $20 \%$ \\
\hline $\begin{array}{l}\text { THE DOCTORE } \\
\text { DIDN'T } \\
\text { UNDERSTAND MY } \\
\text { MEDICAL ISSSUES }\end{array}$ & $26.7 \%$ \\
\hline
\end{tabular}

Table no. 15 represents that $53.3 \%$ people faced issue regarding TELEMEDICINE CONSULTANT GAVE APPOINTMENT WITHOUT EXAPLAINING THE PROBLEM OF THE PATIENT, 20\% people faced issue because THEIR PROBLEM WAS NOT

SOLVED \& $26.7 \%$ people faced issue because THEIR DOCTOR DIDN'T UNDERSTAND THEIRMEDICAL ISSUES.

TABLE NO. 16

\begin{tabular}{|l|l|}
\hline VARIABLE & PERCENTAGE \\
\hline $\begin{array}{l}\text { THE DOCTOR'S } \\
\text { VOICE WAS NOT } \\
\text { CLEAR }\end{array}$ & $10 \%$ \\
\hline $\begin{array}{l}\text { POOR NETWORK } \\
\text { CONNECTION }\end{array}$ & $20 \%$ \\
\hline $\begin{array}{l}\text { VIDEO CALLS } \\
\text { DROP OUT }\end{array}$ & $20 \%$ \\
\hline NO ISSUES FOUND & $50 \%$ \\
\hline
\end{tabular}

Table 16 represents the technical difficulties faced by patients during telemedicine consultation. The representation of faced technical difficulties through the graph $16 \&$ table 16 are as follows: $20 \%$ people said they faced VIDEO CALLS DROP OUT, 20\% people said they faced POOR NETWORK CONNECTION, $10 \%$ people said they faced THE DOCTOR'S VOICE WAS NOT CLEAR \& 50\% people FOUND NO ISSUES of technical errors during telemedicine consultation.
TABLE NO. 17

\begin{tabular}{|l|l|}
\hline VARIABLE & PERCENTAGE \\
\hline $\begin{array}{l}\text { HARDER TO } \\
\text { OBTAIN } \\
\text { PRESCRIPTION }\end{array}$ & $30 \%$ \\
\hline $\begin{array}{l}\text { INCREASED WAIT } \\
\text { TIME }\end{array}$ & $13.3 \%$ \\
\hline NO ISSUES FACED & $56.7 \%$ \\
\hline
\end{tabular}

Table 17 represents the issues faced for obtaining prescriptions of the telemedicine consultation. The representation of issues faced for obtaining prescriptions of the telemedicine consultation through the graph $17 \&$ table 17 are as follows: $13 \%$ people said they faced INCREASED WAIT TIME ,30\% people said they faced HARDER TO OBTAIN PRESCRIPTION \& $56.7 \%$ people faced NO ISSUES for obtaining prescriptions of the telemedicine consultation.

TABLE NO. 18

\begin{tabular}{|l|l|}
\hline VARIABLE & PERCENTAGE \\
\hline BETTER & $26.7 \%$ \\
\hline JUST AS GOOD & $10 \%$ \\
\hline WORSE & $63.3 \%$ \\
\hline
\end{tabular}

Table 18 represents that $26.7 \%$ people had BETTER experience of telemedicine consultation compared to in-person visit, $63.3 \%$ people has JUST AS GOOD experience of telemedicine consultation compared to in-person visit, $10 \%$ people had WORSE experience of telemedicine consultation compared to in-person visit.

TABLE NO. 19

\begin{tabular}{|l|l|}
\hline VARIABLE & PERCENTAGE \\
\hline $\begin{array}{l}\text { NOT AS } \\
\text { COMPREHENSIVE } \\
\text { OR } \\
\text { THOROUGH }\end{array}$ & $40 \%$ \\
\hline TIME PRESSURE & $50 \%$ \\
\hline
\end{tabular}




\begin{tabular}{|ll|l|}
\hline LACK OF & $10 \%$ \\
CONFIDENCE & IN & \\
ASSESSMENT & & \\
\hline
\end{tabular}

Table 19 represents that $10 \%$ people felt LACK OF CONFIDENCE IN ASSESSMENT in doctor during consultation, 50\% people felt TIME PRESSURE in doctor during consultation \& $40 \%$ people felt NOT AS COMPREHENSIVE OR THOROUGH during telemedicine consultation.

TABLE NO. 20

\begin{tabular}{|l|l|}
\hline VARIABLE & PERCENTAGE \\
\hline $\begin{array}{l}\text { GREATER COST } \\
\text { THAN IN-PERSON } \\
\text { MEDICAL VISIT }\end{array}$ & $20 \%$ \\
\hline $\begin{array}{l}\text { SAME COST AS IN- } \\
\text { PERSON }\end{array}$ & $36.7 \%$ \\
MEDICAL VISIT & \\
\hline $\begin{array}{l}\text { LOWER COST } \\
\text { THAN IN-PERSON } \\
\text { MEDICAL VISIT }\end{array}$ & $43.3 \%$ \\
\hline
\end{tabular}

Table 20 represents that in terms of cost saving in telemedicine $20 \%$ people felt GREATER COST THAN IN-PERSON MEDICAL VISIT, 43.3\% people felt LOWER COST THAN IN-PERSON MEDICAL VISIT \& $36.7 \%$ people felt SAME COST AS IN-PERSON MEDICAL VISIT.

TABLE NO. 21

\begin{tabular}{|l|l|}
\hline VARIABLE & PERCENTAGE \\
\hline YES & $90 \%$ \\
\hline NO & $10 \%$ \\
\hline
\end{tabular}

Table 21 represents the understanding of consultation with health care provider through telemedicine. It shows that $90 \%$ people said YES, means they understand the telemedicine consultation with health care provider, \& $10 \%$ people said NO, means they don't understand the consultation with health care provider through telemedicine.

TABLE NO. 22

\begin{tabular}{|l|l|}
\hline VARIABLE & PERCENTAGE \\
\hline
\end{tabular}

\begin{tabular}{|l|l|}
\hline YES & $6.7 \%$ \\
\hline NO & $93.3 \%$ \\
\hline
\end{tabular}

Table 22 represents if sufficient time provided by healthcare while telemedicine consultation. It shows that $93.3 \%$ people said YES, means $93.3 \%$ people think that health care provider give sufficient time while telemedicine consultation \& $6.7 \%$ people said NO, means $6.7 \%$ people think that health care provider don't give sufficient time while telemedicine consultation.

TABLE NO. 23

\begin{tabular}{|l|l|}
\hline VARIABLE & PERCENTAGE \\
\hline VERY SATISFIED & $63.3 \%$ \\
\hline SATISFIED & $10 \%$ \\
\hline NEUTRAL & $3.3 \%$ \\
\hline DISSATISFIED & $23.3 \%$ \\
\hline $\begin{array}{l}\text { VERY } \\
\text { DISSATISFIED }\end{array}$ & \\
\hline
\end{tabular}

Table 23 represents the satisfaction with provider's thoroughness while using telemedicine consultation. It shows that $63.3 \%$ people said they are SATISFIED, $23.3 \%$ people said they are VERY SATISFIED, 3.3\% people said they are DISSATISFIED \& $10 \%$ people said they feel NEUTRAL about the satisfaction with provider's thoroughness while using telemedicine consultation.

TABLE NO. 24

\begin{tabular}{|l|l|}
\hline VARIABLE & PERCENTAGE \\
\hline YES & $93.3 \%$ \\
\hline NO & $6.7 \%$ \\
\hline
\end{tabular}

Table 24 represents that $93.3 \%$ people

RECOMMENDED OF USING TELEMEDICINE TO A FAMILY MEMBER OR FRIEND \& $6.7 \%$ people DON'T RECOMMEND USING OF 
TELEMEDICINE TO FAMILY MEMBER OR FRIEND.

TABLE NO. 25

\begin{tabular}{|l|l|}
\hline VARIABLE & PERCENTAGE \\
\hline YES & $53.3 \%$ \\
\hline NO & $6.7 \%$ \\
\hline MAYBE & $40 \%$ \\
\hline
\end{tabular}

Table 25 represents that $53.3 \%$ people PREFER \& $6.7 \%$ people DON'T PREFER using telemedicine consultation in future for health issues and $40 \%$ people said MAY BE, means they maybe prefer using telemedicine consultation in future for health issues.

TABLE NO. 26

\begin{tabular}{|l|l|}
\hline VARIABLE & PERCENTAGE \\
\hline $\begin{array}{l}\text { NOT } \\
\text { USEFUL }\end{array}$ & $13.3 \%$ \\
AT ALL & \\
\hline VERY & $86.7 \%$ \\
USEFUL & \\
\hline
\end{tabular}

Table 26 represents usefulness of medical appointment with telemedicine after the COVID 19 emergency is over. It shows that $86.7 \%$ people think medical appointment with telemedicine is VERY USEFUL after COVID $19 \& 13.3 \%$ people think medical appointment with telemedicine is NOT USEFUL AT ALL after COVID 19.

\section{CONCLUSION}

The COVID-19 pandemic is making many changes and increasing the need of telemedicine consultation. The current study revealed adequate satisfaction of patients towards telemedicine consultation services in the time of COVID-19. According to me the pandemic outbreak has given an opportunity to promote telemedicine more vigorously. Although most participants were satisfied with current telemedicine and willing to use it in the future, but also a small yet still significant portion of participants still prefer an inperson meeting with a physician. In short, the
COVID-19 pandemic has promoted the use of telemedicine.

\section{REFERENCE}

1. What is telemedicine (telehealth)? Definitionfrom WhatIs.com (techtarget.com)

2. The WHO Just Declared Coronavirus COVID19 a Pandemic $\mid$ Time 